\title{
Lower Cretaceous Orbitolinid (Foraminiferida) Record from the Southwest of Iran (Zagros, Shiraz)
}

\author{
Mahnaz Parvaneh Nejad Shirazi ${ }^{{ }^{*}}$, Fatemeh Abedi $^{2}$ \\ ${ }^{1}$ Department of Geology, Payame Noor University, Tehran, Iran \\ ${ }^{2}$ Water Company, Lamerd, Iran \\ Email: ${ }^{*}$ mahnaz402002@yahoo.com
}

Received November 1, 2012; revised December 2, 2012; accepted January 3, 2013

\begin{abstract}
A biostratigraphic study was carried out in the Lower Creaceous (Aptian-lower Albian) Zagros basin, northeastern Shiraz located at southwestern Iran, allowing the recognition of one lithostratigraphic unit. The Lower Cretaceous shallow-water limestones on the northeast of Shiraz contains abundant and diversified orbitolinid foraminifera. A biostratigraphy, based on the orbitolinid taxa and their distribution, is proposed for the Aptian and Albian deposits in the Lower Creaceous (Aptian-lower Albian) Zagros basin, northeastern Shiraz located at southwestern Iran, allowing the recognition of one lithostratigraphic unit. Three orbitolinid biozones have been recognized: 1) Palorbitolina lenticularis Assemblage Zone in the Lower Aptian; 2) Mesorbitolina parva Total Range Zone in the Late Aptian; 3) Orbitolina (Mesorbitolina) texana Assemblage Zone in the uppermost Aptian-lower Albian, the body of strata being characterized by a distinctive assemblage of Orbitolina (Mesorbitolina) texana and O. (M.) parva. The following taxa are the most abundant: Mesorbitolina texana, Mesorbitolina parva, Orbitolina sp., Pseudocyclammina lituus, Pseudochrysalidina conica, Pseudochrysalidina cf. arabica, Pseudocyclammina hedbergi, Praechrysalidina infracretacea, Cuneolina pavonia, Dictyocunus arabicus, Iraqia simplex, Vercosella laurentii, Protomarssonella trochus, Nautiloculina oolithica, and calcareous algae such as Salpingoporella dinarica, Trinocladus tripolitanus, Terquemella sp. and Lithocodium aggregatum-Bacinella irregularis.
\end{abstract}

Keywords: Aptian-Early Albian; Orbitolinid; Foraminifera; Zagros; Shiraz

\section{Introduction}

The Orbitolinidae are large benthic foraminifers with highest diversities in the Early to Mid-Cretaceous. This family flourished in shallow marine carbonate facies deposited under subtropical to tropical conditions. The species have relatively short temporal ranges and thus provide valuable chronostratigraphic information $[1,2]$. Furthermore, orbitolinids are important as indicators of tropical climates typical for the Tethyan Realm [3].

The Daryian Formation is regionally significant as a petroleum reservoir and a source rock in the Zagros Ba$\sin$ [4]. The Daryian Formation is equivalent to the Shoabia Formation in neighboring Saudi Arabia, Iraq and Qwit [5]. James and Wynd [6] studied the stratigraphic relationships of the Daryian Formation at Gadun Mountain in the Zagros Foldbelt, but the age of the unit remains being poorly resolved. This study aims to document the foraminiferal fauna and calcareous algal flora in the formation in order to resolve the age of the unit and to clarify its depositional environment.

\footnotetext{
"Corresponding author.
}

The Aptian-early Albian (Daryian Formation) was studied in detail and formally defined by James and Wynd [6]. Biostratigraphic criteria of the Daryian Formation were also studied by James and Wynd [6]. Lithological and microfaunal characteristics of the Daryian Formation were studied by Gollestaneh [7], Kheradpir [8], Ghavidel Syooki [9] and Kalantari [10]. More recent studies were undertaken by Parvaneh Nejad Shirazi [11, 12].

\section{Geological Setting}

The Zagros Mountain ranges dominate southwestern Iran. The study area lies in the Zagros Basin, which developed on the northeastern continental margin of Africa during the Paleozoic Era. During the Permian Period, detachment of the Iran plate (comprising Alborz, the east-central Iran microcontinent and Sanandaj-Sirjan) from the Arabian plate caused the formation of the Neotethyan Ocean. Individual microcontinents later detached from this assemblage and followed a northward path, before suturing to Eurasia before and during the Miocene Epoch, when Africa collided with Eurasia. The Alpidic-Himalayan 
Orogeny caused major deformation of all Iranian terranes and generated their present con Figureuration (Berberian et al. [13]; Alavi [14]; Golonka [15].

The study area $\left(29^{\circ} 53^{\prime} 1 " \mathrm{~N}, 52^{\circ} 56^{\prime} 4^{\prime \prime} \mathrm{E}\right.$; Figure 1) is approximately $50 \mathrm{~km}$ north-northwest of Shiraz city. The paved road from Shiraz to Marvdasht is the main access road to Rahmat Mountain. The studied section is $285.5 \mathrm{~m}$ thick and is within the Rahmat Anticline. The Aptianearly Albian deposits (Daryian Formation) is composed of medium to thick-bedded limestone containing Orbitolina. The lower boundary of the Daryian Formation with the Gadvan Formation is gradational, and its upper boundary with the Kazhdumi Formation is disconformable Abbreviations and Acronyms.

This paper is the first report on the biostratigraphy of the Aptian-early Albian deposits (Dariyan Formation) at the southwest of Iran (Shiraz).

\section{Materials and Methods}

During field work in the Shiraz area, one stratigraphic section of the Lower Cretaceous was studied. The material consists of limestone samples. Stratigraphic unit (Figure 2) was analyzed in detail. This unit was measured in the whole part of the Aptian-early Albian deposits (Dariyan Formation). Additional samples from other localities were collected in isolated outcrops in order to complete our understanding of faces variation and age. More than eighty oriented surface samples were collected and thin sections were prepared, and the benthic foraminiferal assemblages were examined. Well-oriented thin sections were obtained for study of the morphology of the foraminifera. Stereo microscope Olympus was used for the paleontology studies and taking microphotographs from 48 selected thin sections. The identification of foraminiferal fossils is based on Loeblich and Tapan [16], the algal study is based on Delloffre [17] and Bassoullet et al. [18], and the microfacies study is based on Dunham [19], Wilson [20] and Flügel [21]. Field and laboratory descriptions of the samples were plotted on a stratigraphic section. All slides used in this study are on file at the Payame Noor University Branch in Shiraz.

Field work was concentrated at the southwestern flank of the Rahmat Anticline, in the vicinity of Rostamabad village. A section was measured in detail along a slope crossing the southwestern trend of the anticline.

The foraminiferal assemblages of the Aptian-early Albian deposits (Dariyan Formation) consist of various agglutinate foraminifera. This fauna is a good tool for biofacies analysis, recognition of paleoecology and lithostratigraphy.

\section{Result and Discussion}

A biostratigraphic zonation for the Cretaceous System in southwest Iran was established by James and Wynd [6], Gollestaneh [7], Sampo [22] and Kheradpir [8].

In dating the lower Cretaceous rocks, the biostratigraphy of all the foraminifers and calcareous algae were taken into account, and three biozones were recognized in the studied area.

\section{Biozonation}

This study aims to summarize the stratigraphic range of the assemblage zones and the species that occur in the Aptian-early Albian (Daryian Formation) and to compare these data with zonations that have been recorded for the Zagros Basin. Three zones were established. We discuss them below in ascending stratigraphic order (Figure 2).

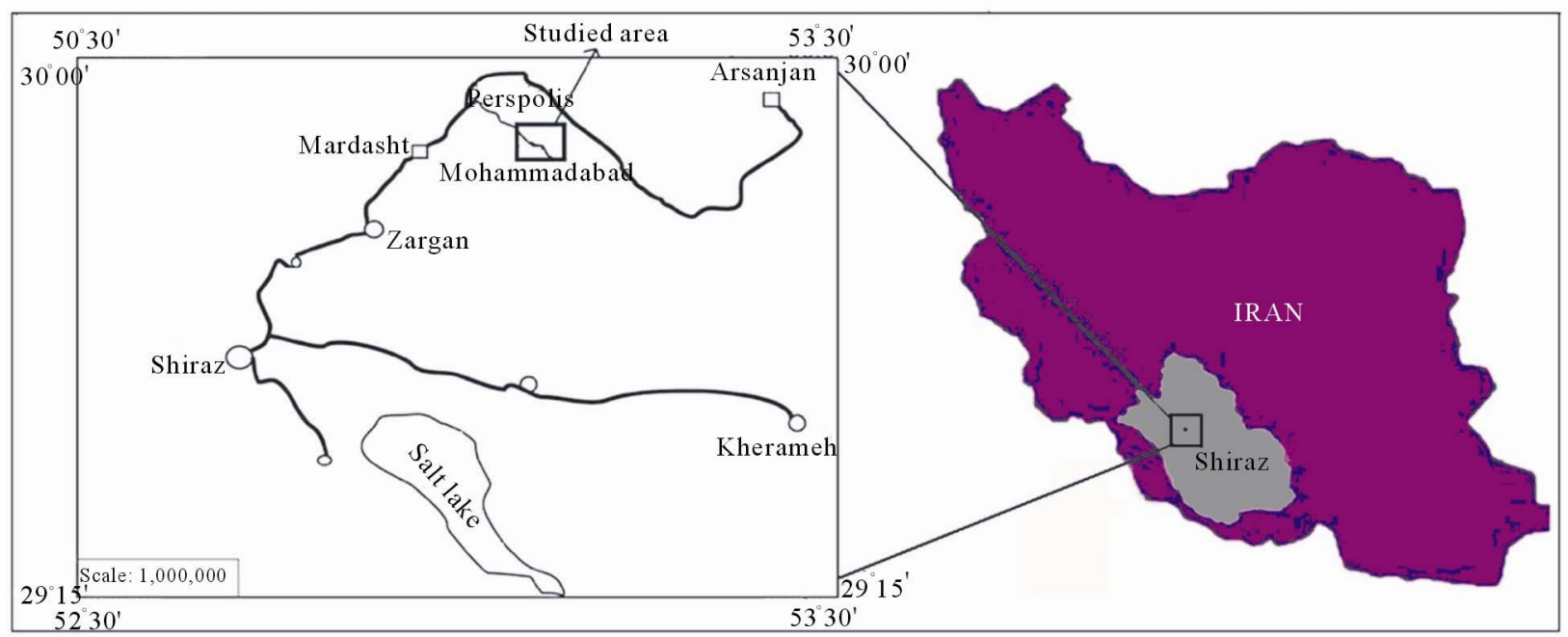

Figure 1. Location map of Iran and conection of Shiraz to the studied area. 


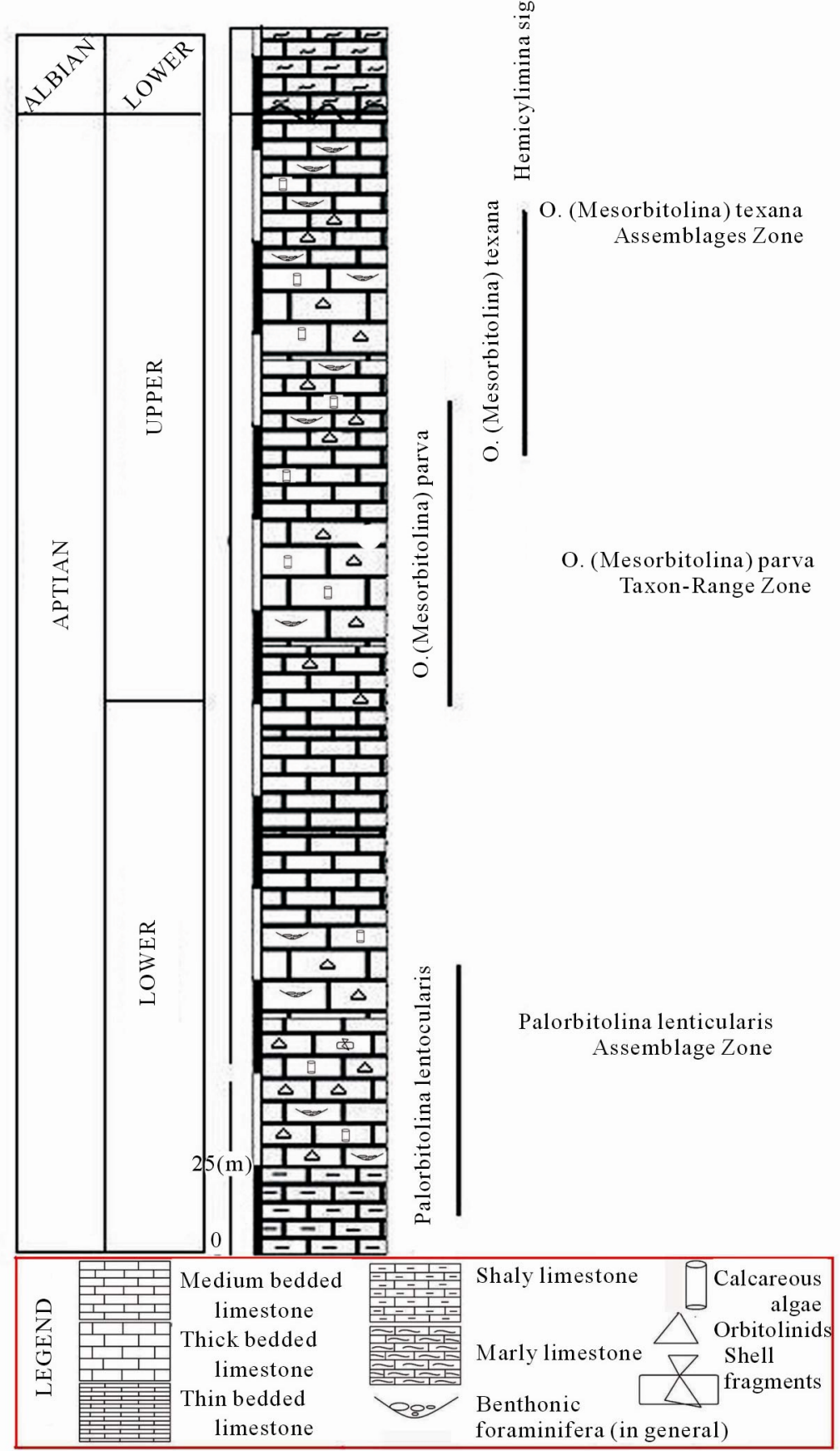

Figure 2. Schematic geological column of the studied area with stratigraphic distribution of the orbitolinid taxa.

Palorbitolina lenticularis Assemblage Zone: A very rich microfossil association characterizes the Palorbitolina lenticularis Assemblage Zone. This zone is characrerized by presence of Choffatella decipiens (Figure 3(a)), Debarina haurensis, Dictyocunus arabicus, Vercosella laurentii (Figure 3(d)), Praechrysalidina infracretacea, Pseudochrysalidina cf. arabica and calcareous algae such as Salpingoporella dinarica (Figure 3(h)), Permocalcaleus cf. inopinatus. The strata reflect deposi- tion during the early Aptian. Aptian deposits are characterized by development of Palorbitolina-limestones during the early Aptian ("Lower orbitolinid limestones" Velic and Sokac [23], and Velic and Tisljar [24], and both maximal development of the alga Salpingoporella dinarica Radoicic and the first appearance of large $\mathrm{Me}$ sorbitolina during the late Aptian.

Mesorbitolina parva Total Range Zone: This zone begins at the middle part of Daryian Formation and extends 

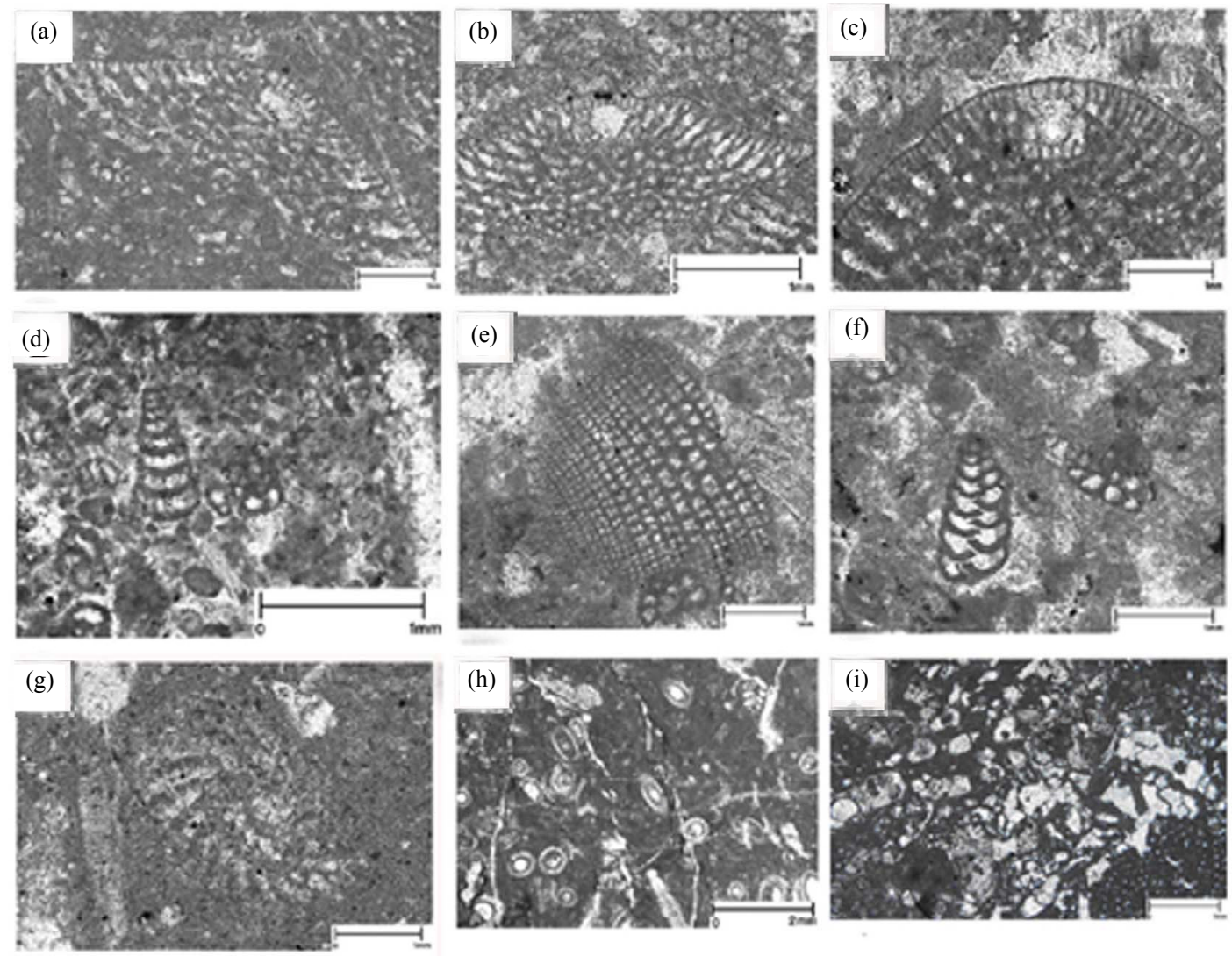

Figure 3. (a) Palorbitolina lenticularis BLUMENBACH. Axial section through megalospheric embryonic apparatus; (b) Orbitolina (Mesorbitolina) texana ROEMER. Axial section through megalospheric embryonic apparatus; (c) Orbitolina (Mesorbitolina) parva DOUGLASS. Axial section through megalospheric embryonic apparatus; (d) Vercosella laurentii SARTONI \& CRESECENTI. Longitudinal section along the long axis; ((e), (f)) Cuneolina pavonia D’ORBIGNY; (e) Tangential section; (f) Longitudinal section along the long axis; (g) Choffatella decipiens (SCHLUMBERGER). Equatorial section; (h) Salpingoporella dinarica RADOICIC. Oblique section; (i) Lithocodium aggregatum ELLIOTT.

through a thickness of $50 \mathrm{~m}$. This zone is characterized by the presence of Orbitolina (Mesorbitolina) parva, Orbitolina (Mesorbitolina) texana, Pseudochrysalidina conica, Everticyclammina hedbergi, Praechrysalidina infracretace and calcareous algae including Lithocodium aggregatum (Figure 3(i)) (syn Bacinella irregularis) and Trinocladus tripolitanus. This zone is considered to belong to the late Aptian on the basis of foraminifers.

Orbitolina (Mesorbitolina) texana Assemblage Zone: The Orbitolina (Mesorbitolina) texana Assemblage Zone comprises strata that contain a distinctive assemblage of the following taxa: O. (M) texana and $O$. (M) parva, Cuneolina pavonia.

This assemblage zone occurs the uppermost of the Daryian Formation. This zone is characterized by foraminifers such as $O$. (M) texana (Figure 3(b)), O. (M) parva (Figure 3(c)), Orbitolina sp., Pseudocyclammina lituus, Pseudochrysalidina conica, Everticyclammina hedbergi, Cuneolina pavonia, Dictyocunus sp., Iraqia simplex, Protomarssonella trochus, Quinqueloculina sp., Nautiloculina oolithica, Ammobaculites sp. and Hap- lofragmoiedes sp. On the basis of index fossils, this foraminiferal assemblage zone is considered to belong to the uppermost Aptian-early Albian. Calcareous algae include Trinocladus tripolitanus, Terquemella sp., Lithocodium aggregatum-Bacinella irregularis.

\section{Paleoecology and Paleoenvironment of Foraminifera}

Studies of foraminiferal ecology have provided at least five distinct criteria for the reconstruction of marine paleoenvironments (Naish et al. [25]: 1) both the number of species and specimen abundance increase away from shore and with increasing depth of water to maximum values on the outer shelf and in the upper and middle bathyal zone; 2) diverse porcelaneous species are abundant in shoal near-shore marine environments; 3) arenaceous foraminifers with simple interiors may be abundant in shallow waters, whereas more complex types with labyrinthic interiors are more characteristic of bathyal depths; 4) deposition of planktic species occurs most abundantly on the outer shelf and in the upper bathyal zone, 
with even greater abundances in deeper waters under the right conditions; and 5) similar environmental adaptations of modern species and fossil homomorphs (and isomorphs) may be assumed, especially for groups of species.

The paleoecology of foraminifers in the Daryian Formation at Rahmat Mountain has been determined on the basis of the biozones studied. The Mesorbitolina texana-Pseudocyclammina lituus assemblage zone is characterized by large and agglutinated foraminifers such as Mesorbitolina and Pseudocyclammina. The Mesorbitolina has a high variety, which suggests a shallow-marine environment and indicates the beginning of the Daryian Formation. Among the dominant benthic foraminifers, Orbitolina, Dictyoconus, Iraqia, Pseudochrysalidina and Pseudocyclammina are the main genera recorded in the present work, reaching to $50 \%$ of the skeletal components and mainly represented by the oncoidal and concoidal orbitolinids. A miliolid-dominant facies is also recorded. In the Aptian-Albian beds (mainly limestone), benthic foraminifers are dominant.

The biotic distribution was controlled largely by paleoenvironmental changes, such as trophic level, water energy and clay influx, as well as sedimentary factors controlled by variations in accommodation space. In particular, in the Albian the biotic components and their ecological requirements indicate shallow-water carbonate facies characterized by shallow, warm and saline water conditions with different degrees of water energy that change to relatively deeper water in some parts of the area.

The association of orbitolinids with calcareous algae and echinoderms in slightly argillaceous limestones, as indicated from the present work, are interpreted to have been deposited in relatively high trophic conditions (mesotrophic).

Changes in trophic level might be related to variable humidity conditions during sea-level rise and fall. The increased weathering rates during early transgression, induced by stronger rainfall and clay reworking during flooding of exposed platforms, may have contributed to the onset of mesotrophic conditions favorable for the development of orbitolinids. Orbitolinid-rich facies occur generally contemporaneously from inner to outer platforms and in intrashelf basins. The overall pattern of the Albian sequence seems to indicate a regressive shallowmarine setting for the deposition of the upper Daryian succession. This succession represents shallow shelf sequences composed generally of limestones rich in benthic foraminifers.

Carbonate rocks of the Daryian Formation were deposited in tidal-flat, lagoon, bar and open-marine facies belts.

\section{Conclusions}

A rich foraminiferal, especially orbitolinid, association has been determined within Aptian-early Albian limestone deposits on the northwest of Shiraz (Zagros).

Three biostratigraphic zones have been estab lished based on the orbitolinid taxa and their stratigraphic distribution.

The age of the Daryian Formation is Aptian-early Albian. This formation is represented by medium to thickbedded limestone containing Orbitolina in the Zagros Basin. The Daryian Formation overlies the Gadvan Formation and is overlain by the Kazhdumi Formation.

Orbitolinids in association with calcareous algae and echinoderms in slightly argillaceous limestones, as indicated in the present work, are interpreted to have been deposited in relatively high trophic conditions (mesotrophic).

\section{Acknowledgements}

We are grateful to the students of Payam Noor University, Shiraz branch, for physical support during our field work.

\section{REFERENCES}

[1] A. Arnaud-Vanneau, "Larger Benthic Foraminifera," In: P.-C. De Graciansky, J. Hardenbol, T. Jacquin and P. R. Vail, Eds., Mesozoic and Cenozoic Sequence Stratigraphy of European Basins, Special Publication, Society of Economic Paleontologists and Mineralogists, Tulsa, 1998, pp. 721-733. books.google.com/books?isbn $=1862393060$

[2] R. Schroeder, F. S. P. Van Buchem, A. Cherchi, D. Baghbani, B. Vincent, A. Immenhauser and B. Granier, "Revised Orbitolinid Biostratigraphic Zonation for the Barremian-Aptian of the Eastern Arabian Plate and Implications for Regional Stratigraphic Correlations," GeoArabia Special Publication 4, Vol. 1, 2010, pp. 49-96. http://perso-sdt.univ-brest.fr/ bgranier/geologie/paleontol ogie/pdf/072-granier.pdf

[3] J.-P. Masse, "The Lower Cretaceous Mesogean Benthic Ecosystems: Palaeoecologic Aspects and Palaeobiogeographic Implications," Palaeogeography, Palaeoclimatology, Palaeoecology, Vol. 91, 1992, pp. 331-345. www.mendeley.com/.../the-lower-cretaceous-mesogeanbenthic-ecosystems-paleoecological-aspects-and-paleo-biogeographic-implications

[4] H. Afsharharb, "Petroleum Geology of Iran," Engineering Faculty of Tehran University, Tehran, 2001. books.google.com/books?isbn=1862392714

[5] H. Motiei, "Stratigraphy of Zagros: Treatise of Geology of Iran," Natural Iranian Oil Company, Tehran, 1993. books.google.com/books?isbn=1862392935

[6] G. A. James and J. G. Wynd, "Stratigraphic Nomenclature of Iranian Oil Consortium Agreement Area," American Association of Petroleum Geologists Bulletin, Vol. 49, No. 12, 1965, pp. 2192-2245.

http://aapgbull.geoscienceworld.org/content/49/12/2182.a bstract 
[7] A. Gollestaneh, "An Introduction to the Stratigraphic Distribution of Fossil Calcareous Algae in Southern Iran," Iranian Oil Operating Companies, Geological and Exploration Division, Tehran, 1966.

http://www.nioclibrary.ir/simwebclt/WebAccess/Simweb Portal.dll

[8] A. Kheradpir, "Stratigraphy of the Khami Group in Southwest Iran," IOSC (NIOC), Tehran, 1975. http://books.google.com/books?id=Sg_mTTDypwwC\&p $\mathrm{g}=$ PA250\&lpg=PA250\&dq=Kheradpir

[9] M. Ghavidel Syooki, "Palynological Environmental Age Determination of Dariyan Formation," NIOC, Exploration and Technology Division, Tehran, 1979. www.ghavidelsyooki.com/.../PALYNOSTRATIGRAPH $\mathrm{Y}$

[10] A. Kalantari, "Microbiostratigraphy of Sarvestan Area, Southwestern Iran," National Iranian Oil Company, Tehran, 1986.

books.google.com/books/.../Microbiostratigraphy_of_the Sarvestan_ar.html?

[11] M. P. N. Shirazi, "Calcareous Algae from the Cretaceous of Zagros Mountains (SW Iran)," World Applied Sciences Journal, Vol. 4, No. 6, 2008, pp. 803-807. idosi.org/wasj/wasj4(6)/7.pdf

[12] M. P. N. Shirazi, "Albian-Cenomanian Zonation (Foraminifers and Calcareous Algae) in the Northern Fars, Iran," American Journal of Applied Sciences, Vol. 6, No. 4, 2009, pp. 709-714.

thescipub.com/pdf/10.3844/ajassp.2009.709.714

[13] M. Berberian and G. C. P. King, "Towards a Paleogeography and Tectonic Evolution of Iran," Canadian Journal of Earth Science, Vol. 18, No. 2, 1981, pp. 210-265. DOI: $10.1139 / \mathrm{e} 81-019$

[14] M. Alavi, "Tectonics of the Zagros Orogenic Belt of Iran: New Data Interpretations," Tectonophysics, Vol. 229, No. 3-4, 1994, pp. 211-238.

http://journals.ut.ac.ir/page/issue-main-page.html?issueId $=1000012$

[15] J. Golonka, "Cambrian-Neogene Plate Tectonic Maps," Institute of Geological Sciences, Jagiellonian University, Kraków, 2000. ww.dinodata.info/ Golonka/phan.pdf

[16] A. R. Loeblich Jr. and H. Tappan, "Foraminifera Genera and Their Classification," Van Nostrand Reinhold, New York, 1988.

http://www. foraminifera.eu/ko-weddellXXII3-f01.html
[17] R. Delloffre, "Nouvelle Taxonomic des Algues Dasycladales (New Taxonomy of Dasycladale Algae)," Bulletin des Centre de Recherches Exploration-Production ElfAquitaine, Vol. 12, No. 1, 1988, pp. 165-217.

http://www.antiqbook.nl/boox/aquila/2045.shtml

[18] J. P. Bassoullet, P. Bernier, M. A. Conrad, R. Deloffre and M. Jafrezo, "Les Algues Dasycladales du Jurassique et du Cretace," Geobios Memoire Special, Vol. 2, No. 8, 1978, pp. 259-290.

http://www.sciencedirect.com/science?_ob=PublicationU RL\& tockey=\#TOC\#7224\#1978

[19] R. J. Dunham, "Classification of Carbonate Rocks according to Depositional Texture," American Association of Petroleum Geologists Bulletin, Vol. 43, No. 1, 1962, pp. 108-121.

[20] J. L. Wilson, "Carbonate Facies in Geologic History,” Springer-Verlag, New York, 1975.

http://journals.cambridge.org/action/displayFulltext?type $=1 \&$ fid $=4571384 \&$ jid=GEO\&volumeId=113\&issueId=06 \&aid $=4571380$

[21] E. Flügel, "Microfacies of Carbonate Rocks: Analysis, Interpretation and Application," Springer-Verlag, BerlinHeidelberg, 2004.

[22] M. Sampo, "Microfacies and Microfossils of the Zagros Area, SW Iran (from the Permian to Miocene)," International Sedimentary Petrographical Series, Vol. 12. No. 1, 1969, p. 102.

books.google.com/books?isbn=364203795X

[23] I. Velić and B. Sokač, "Biostratigraphic Analysis of the Jurassic and Lower Cretaceous in the Wider Region of Ogulin, Central Croatia," Geološki Vjesnik, Vol. 30, No. 1, 1978, pp. 309-337.

[24] I. Velić and J. Tisljar, "Biostratigraphic and Sedimentologic Characteristics of the Lower Cretaceous Deposits of the Veli Brijun Island and Comparison with the Corresponding Deposits in SW Istria (Western Croatia, Yugoslavia)," Geološki Vjesnik, Vol. 40, No. 1, 1987, pp. 149-168.

http://www.google.com/url?q=http://hrcak.srce.hr/file/61 $02 \&$ sa

[25] T. Naish and P. J. J. Kamp, "Foraminiferal Depth Palaeoecology of Late Pliocene Shelf Sequences and Systems Tracts, Wanganui Basin, New Zealand," Sedimentary Geology, Vol. 110, No. 3-4, 1997, pp. 237-255. doi:10.1016/S0037-0738(96)00085-1 